\title{
KONSEP PERENCANAAN TATA HIJAU LANSKAP SEMPADAN SETU MANGGA BOLONG SEBAGAI AREA KONSERVASI TUMBUHAN BERNILAI EKOLOGIS DAN BUDAYA
}

\author{
Sitti Wardiningsih ${ }^{1,}$, Ray March Syahadat ${ }^{1}$, Priambudi Trie Putra ${ }^{1}$, Retno Purwati ${ }^{1}$, \\ Moh. Sanjiva Refi Hasibuan'. \\ ${ }^{1}$ Program Studi Arsitektur Lanskap, Fakultas Teknik Sipil dan Perencanaan, \\ Institut Sains dan Teknologi Nasional, Jl.Moh Kahfi II Srengseng Sawah Jagakarsa Jakarta Selatan, \\ 12640 \\ *wardiningsih.sitti@gmail.com
}

\begin{abstract}
ABSTRAK. Setu Mangga Bolong memiliki peluang untuk dikembangkan menjadi kawasan konservasi bagi tanaman khas Betawi. Tujuan dari artikel ini adalah untuk merencanakan lanskap sempadan Setu Mangga Bolong dengan konsep ekologis tanpa melupakan identitasnya sebagai kawasan budaya. Untuk mencapai tujuan ini maka dilakukan analisis perubahan lahan selama periode 2005-2015. Penilaian kualitas visual dengan menggunakan metode scenic beauty estimation (SBE), semantic differential (SD), dan multidimensional scalling (MDS). Selanjutnya vegetasi yang ada diinventarisasi. Kemudian, vegetasi dalam peraturan dan kebijakan yang memiliki nilai ekologi dan budaya dipertimbangkan. Hasil yang diperoleh kondisi badan air Setu Mangga Bolong pada periode 20052015 lebih baik dari tahun ke tahun. Meskipun demikian, terjadi penurunan area hijau di sempadan Setu Mangga Bolong selama periode tahun 2005-2015. Berdasarkan hasil analisis kualitas visual, lanskap pada area sudut setu yang berbentuk irregular (cekungan) dan juga sudut setu yang berdekatan dengan inlet memiliki kualitas visual yang rendah. Untuk merencanakan tata hijau sempadan setu sebagai area konservasi tanaman bernilai ekologis dan budaya, empat puluh spesies vegetasi eksisting perlu dipertahankan selama tidak mengganggu kualitas dan kuantitas badan air. Vegetasi terpilih direkomendasikan ke lanskap Setu Mangga Bolong sebagai ruang terbuka hijau yang memiliki fungsi ekologis dan budaya Betawi.
\end{abstract}

Kata kunci: Betawi, regulasi, seleksi, vegetasi

\begin{abstract}
Setu Mangga Bolong has opportunity to be developed into a conservation area for Betawinese plants. The purpose of this article was to plan the landscape of Mangga Bolong Lake with the ecological concept without forgetting its identity as a cultural area. To achieve these objectives, an analysis landuse change on 2005 to 2015 was executed. Visual quality analysis used scenic beauty estimation (SBE), semantic differential (SD) and multidimensional scalling (MDS). Next, inventory of existing vegetation was executed. Then, the vegetation in the regulation and policy on ecological and cultural value was considered. The results howed that water body condition of Setu Mangga Bolong in 2005 to 2015 period is better from year to year. However, there was a decrease of the green area in Setu Mangga Bolong during the period. Based on the results of visual quality analysis, landscape on the irregular edge of lake and close to the inlet, has low visual quality. To plan the green open space of Setu Mangga Bolong as ecologicaland cultural plants conservation, the forty species existing vegetation should be maintained as long as it does not effect for the quality and quantity of water body of the lake. Selected vegetation have been recommended to be applied within Setu Mangga Bolong landscape as green open space that has ecological and cultural functions.
\end{abstract}

Keywords: Betawi, regulation, selection, vegetation

\section{PENDAHULUAN}

Danau, situ, atau juga biasa disebut setu merupakan fitur lanskap yang dramatis dan mempesona. Berbeda dengan sungai, sistem air di setu cenderung statis. Meskipun demikian ekosistem setu merupakan ekosistem yang dinamis yang memiliki manfaat bagi manusia sebagai wadah air, sumber bahan pangan, dan tempat rekreasi. Bukan hanya bermanfaat bagi manusia, setu juga merupakan habitat makhluk hidup lainnya baik flora maupun fauna. Sifat lainnya yaitu setu merupakan ekosistem akuatis yang peka dan rentan terhadap gangguan. Oleh karena itu keberadaan setu dapat menjadi indikator sensitif dan penengara atas dampak yang ditimbulkan. Baik alami maupun akibat dari aktivitas manusia yang ada dalam daerah tangkapan air dan bahkan terkadang juga kegiatan yang terjadi di luar setu [1].

Setu memiliki peranan yang penting dalam pengelolaan air di perkotaan khususnya 
Jakarta. Fungsinya sebagai area tangkapan air semakin terdesak oleh pembangunan yang tidak berwawasan lingkungan. Dampaknya akan terlihat nyata pada kualitas dan kuantitas setu itu sendiri.

Masalah banjir di saat penghujan dan kekeringan saat kemarau merupakan indikasi bahwa pengelolaan setu tidak berjalan dengan baik. Aktivitas manusia juga memberi dampak serius pada setu seperti alih fungsi lahan dari area hijau menjadi nonhijau dan pencemaran dari limbah rumah tangga. Hal ini mengakibatkan eutrofikasi dan pendangkalan setu [2] [3].

Setu Mangga Bolong terletak di Srengseng Sawah, Jagakarsa, Jakarta Selatan. Lokasinya berdekatan dengan Setu Babakan. Baik Setu Mangga Bolong maupun Setu Babakan, keduanya berada dalam manajemen UPT PBB Setu Babakan.

Meskipun berada pada manajemen yang sama dengan Setu Babakan, kondisi Setu Mangga Bolong dapat dikatakan memprihatinkan. Sangat berbeda dengan Setu Babakan yang lebih tertata dan juga dikenal sebagai tempat wisata yang menyajikan keindahan alam berupa pemandangan (view) setu dan atraksi budaya khas Betawi [4] [5] [6]. Padahal Setu Babakan dan Mangga Bolong sejak zaman dulu merupakan satu kesatuan yang tidak dapat dipisahkan. Dulunya kedua setu ini digunakan untuk mengairi persawahan pada area setempat [7].

Sejak lama, masyarakat banyak mengeluhkan kondisi Setu Mangga Bolong yang tidak terurus, pendangkalan, eutrofikasi, tercemar oleh sampah, dan menjadi sarang nyamuk [8] [9]. Untuk itu sejak tahun 2015, Pemerintah Provinsi DKI Jakarta memiliki program untuk merehabilitasi sungai dan setu yang mengalami pendangkalan. Salah satu yang menjadi perhatian Pemerintah Provinsi DKI Jakarta yaitu Setu Mangga Bolong [10] [11]

UPT PBB Setu Babakan sendiri memiliki rencana untuk menjadikan area Setu Mangga Bolong sebagai kawasan konservasi. Hal ini dimaksudkan untuk melengkapi kawasan Setu Babakan yang berperan sebagai kawasan wisata dan pelestarian budaya. Untuk itu perlu dilakukan kajian dan pembuatan konsep zonasi lanskap guna merencanakan tata hijau di Setu Mangga Bolong guna mencapai keberlanjutannya.

\section{METODE PENELITIAN}

Studi dilakukan di Setu Mangga Bolong, Srengseng Sawah, Jagakarsa, Jakarta Selatan selama September 2015 hingga Januari 2016 (Gambar 1). Metode yang digunakan dalam artikel ini yaitu metode kualitatif dan dianalisis secara deskriptif. Data dikumpulkan dengan wawancara mendalam kepada stakeholders terkait. Observasi dilakukan di Setu Mangga Bolong untuk memvalidasi hasil wawancara. Pada tahap observasi juga dilakukan pendataan vegetasi eksisting di Setu Mangga Bolong yang kemudian diolah menggunakan perangkat lunak AutoCAD 2007.

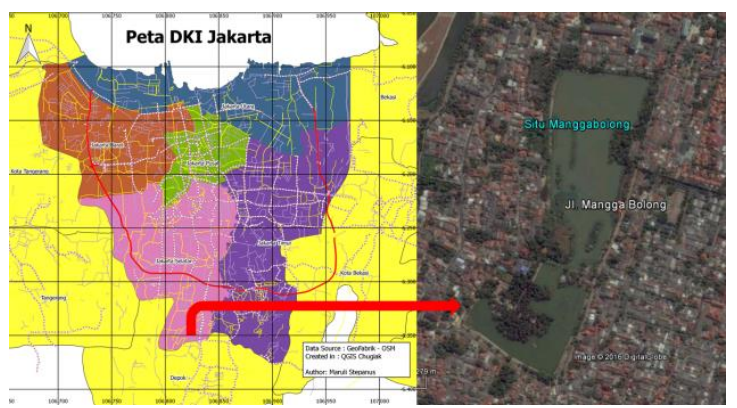

Gambar 1. Denah Lokasi Penelitian (Sumber: images.google.com)

Pada tahap observasi dilakukan pemotretan pada 9 titik yang mewakili lanskap keadaan setu (Gambar 2). Pengambilan gambar dengan format landscape dengan tinggi kamera selevel dada orang dewasa untuk menghindari bias antar gambar [12]. Titik-titik lanskap tersebut selanjutnya dilakukan penilaian kualitas visual setu, dengan menggunakan metode scenic beauty estimation (SBE), kepada 30 responden [13]. Responden diminta untuk memberikan skor pada selang 1 hingga 10 . Derajat paling rendah menunjukkan kualitas lanskap yang rendah sedangkan derajat yang tinggi menunjukkan kualitas visual lanskap yang tinggi. Data diolah dengan menggunakan perangkat lunak Microsoft Excel 2013. Adapun formulanya berdasarkan Daniel dan Boster dijabarkan sebagai berikut:

$$
S B E_{X}=\left(Z_{y x}-Z_{y o}\right) \times 100
$$

Keterangan:

$\mathrm{SBE}_{\mathrm{x}}=$ Nilai pendugaan keindahan pemandangan suatu lanskap ke-x

$Z_{y x}=$ Nilai rata rata $z$ lanskap ke- $x$

$Z_{\text {yo }}=$ Nilai rata rata $\mathrm{z}$ suatu lanskap tertentu sebagai standar 
Guna menilai kesan yang muncul pada lanskap setu maka dilakukan penilaian dengan menggunakan skala semantic differential (SD). Sebanyak 30 responden diminta memberikan bobot nilai pada selang nilai tiap variabel dari 9 titik lanskap setu terhadap kata-kata bipolar Kata-kata bipolar tersebut merupakan kata terseleksi yang mewakili kesan yang timbul ketika memandangi lanskap Setu Mangga Bolong [14]. Data diolah dengan menggunakan perangkat lunak Microsoft Excel 2013. Adapun formulanya sebagai berikut:

$\overline{x_{\imath \jmath}}=\frac{\sum_{i=1}^{n} x_{i j}}{n}$

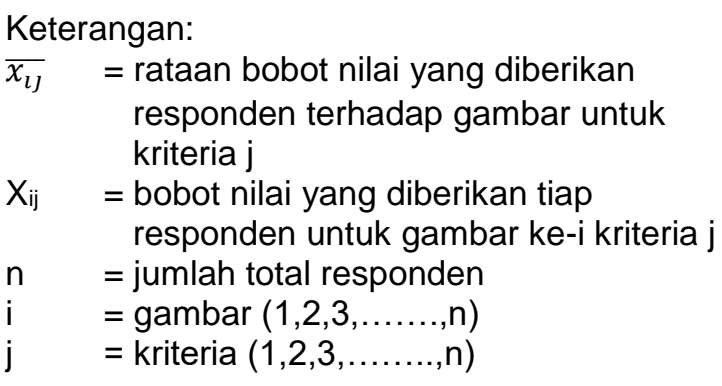

Hasil dari SD dilakukan analisis lanjutan dengan menggunakan analisis multidimensional scaling (MDS). Data diolah dengan menggunakan perangkat lunak IBM SPSS Statistics 22. MDS digunakan untuk memberikan gambaran pada pola kedekatan antara sekumpulan objek. Hasilnya juga nantinya dapat menunjukkan dimensi penilaian langsung dari dari responden kepada pola visualisasi kedekatan mengenai kesamaan lanskap Setu Mangga Bolong.

Pengumpulan data sekunder dilakukan untuk menganalisis potensi dan permasalahan di Setu Mangga Bolong. Analisis perubahan lahan menggunakan peta citra tahun 2005, 2011, dan 2015 yang diperoleh dari Google Earth. Informasi mengenai tanaman langka khas Betawi diperoleh dari SK Gubernur DKI Jakarta nomor 2359 tahun 1987. Selanjutnya ketentuan-ketentuan mengenai pengelolaan setu diperoleh melalui Permen PU Nomor 5 Tahun 2008 tentang Pedoman Penyediaan dan Pemanfaatan Ruang Terbuka Hijau di Kawasan Perkotaan. Konsep perencanaan tata hijau kemudian dideskripsikan dengan gambar yang diolah dengan menggunakan perangkat lunak Adobe Photoshop CS3. Konsep ini berupa zonasi penggunaan tata hijau di sempadan setu.

\section{HASIL DAN PEMBAHASAN}

Berdasarkan hasil analisis tata guna lahan pada tahun 2005 diperoleh gambaran bahwa kondisi Setu Mangga Bolong mengalami pendangkalan. Hal ini sejalan dengan laporan Wardiningsih pada tahun 2005 yang menyatakan bahwa kondisi Setu Mangga Bolong begitu parahnya akibat pengelolaan dan pemanfaatan yang tidak berwawasan lingkungan [9]. Berdasarkan laporan tersebut, badan air dipenuhi bahan organik, sampah padat dan erosi tanah mengalir masuk ke setu. $\mathrm{Hal}$ ini diperparah dengan adanya peternakan dan industri kecil yang mempergunakan bahan-bahan kimia, dialirkan ke setu secara langsung tanpa perlakuan terlebih dahulu. Pada periode ini kondisi Setu Babakan juga tidak lebih baik dari Setu Mangga Bolong (Gambar 3).

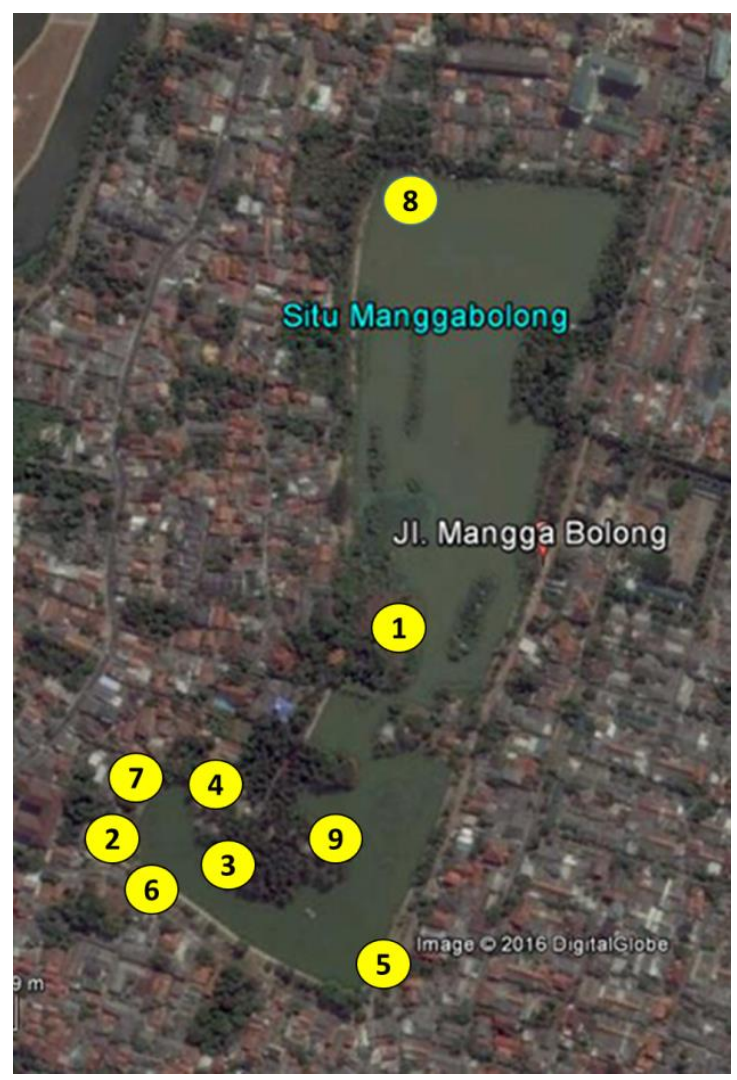

Gambar 2. Sembilan Titik Pengambilan Kualitas Visual Setu Mangga Bolong (Sumber: Google Earth)

Pada tahun 2011, terlihat kondisi Setu Babakan sedikit lebih baik dari Setu Mangga Bolong (Gambar 4). Meskipun kualitas batas setu (sempadan) dan vegetasi tutupan air masih cenderung buruk menurut kriteria dan indikator kualitas setu yang dikemukakan Fauzi [15]. Hal ini dikarenakan Pemerintah Provinsi DKI Jakarta saat itu gencar dalam 
merehabilitasi Setu Babakan sebagai pusat budaya Betawi. Ruang terbuka hijau di sekitar Setu Mangga Bolong mengalami penurunan sepanjang periode 2005-2011. Hal ini pernah dijelaskan oleh Sitorus et al., yang menyatakan bahwa terjadi perubahan luas ruang terbuka hijau di Jakarta Selatan yang diakibatkan oleh beberapa faktor seperti fasilitas kesehatan, jumlah pendatang, kepadatan penduduk, dan fasilitas pendidikan [16].

Memasuki tahun 2015, kondisi badan air Setu Mangga Bolong sebagian besar sudah bebas dari pendangkalan. Hal ini dikarenakan adanya program rehabilitasi beberapa setu di Jakarta, salah satunya yaitu Setu Mangga Bolong. Meskipun demikian, ruang terbuka hijau khususnya di sempadan Setu Mangga Bolong terlihat semakin berkurang dibandingkan pada periode tahun 2011 akibat desakan permukiman sekitar setu (Gambar 5). Melihat kondisi tersebut maka perlu dilakukan upaya konservasi dan rehabilitasi vegetasi sempadan setu untuk menjaga kualitas serta kuantitas setu.

Kondisi eksisting Setu Mangga Bolong saat ini terlihat lebih bersih dari tahun-tahun sebelumnya. Namun, masalah limbah permukiman dari inlet setu masih menjadi faktor penyebab menurunnya kualitas visual dan juga mengancam kualitas air (Gambar 6). Meskipun saat ini telah dioperasikannya perahu pengangkut sampah setu tetapi belum optimal dalam rangka mencapai tujuan pengelolaan setu.

Penilaian kualitas visual Setu Mangga Bolong menunjukkan titik lanskap 4 dan 6 merupakan lanskap dengan kualitas lanskap visual yang buruk karena nilai SBE berada $<-20$. Titik lanskap 5, 6, dan 8 merupakan lanskap dengan kualitas sedang karena nilai SBE berada pada selang $-20 \leq x \leq 20$. Selanjutnya, nilai $\mathrm{SBE}>20$ menunjukkan kualitas visual yang tinggi. Titik lanskap dengan kualitas yang tinggi yaitu lanskap 1, 2, 7, dan 9 (Gambar 7).

Dari hasil penilaian kualitas visual melalui SBE juga diperoleh hasil yang menarik. Semakin irregular suatu struktur ekologi lanskap dalam hal ini patch, maka semakin besar ancaman terhadap kualitas visual jika tidak dikelola dengan baik. Bentuk patch yang regular memiliki sudut pandang yang luas sehingga apabila adanya gangguan visual akan lebih mudah diabaikan oleh pengamat.

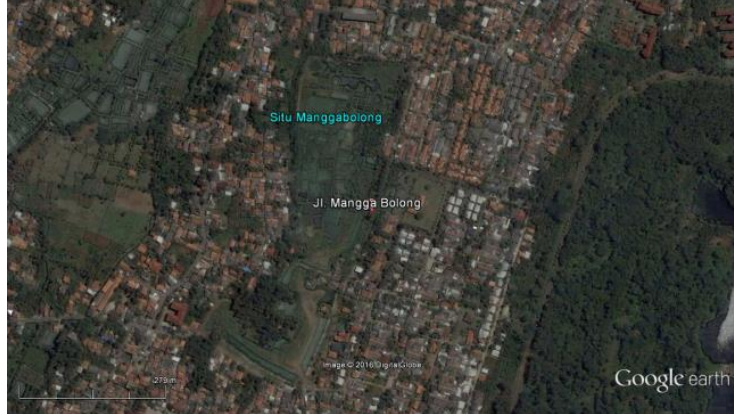

Gambar 3. Peta Citra Setu Mangga Bolong tahun 2005

(Sumber: Google Earth)

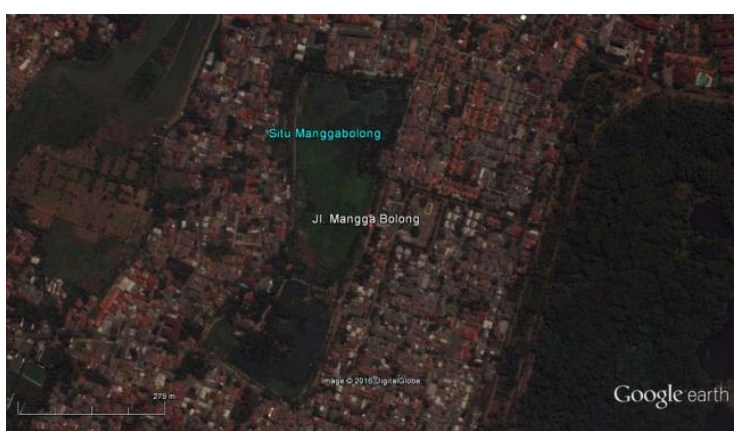

Gambar 4. Peta Citra Setu Mangga Bolong tahun 2011

(Sumber: Google Earth)

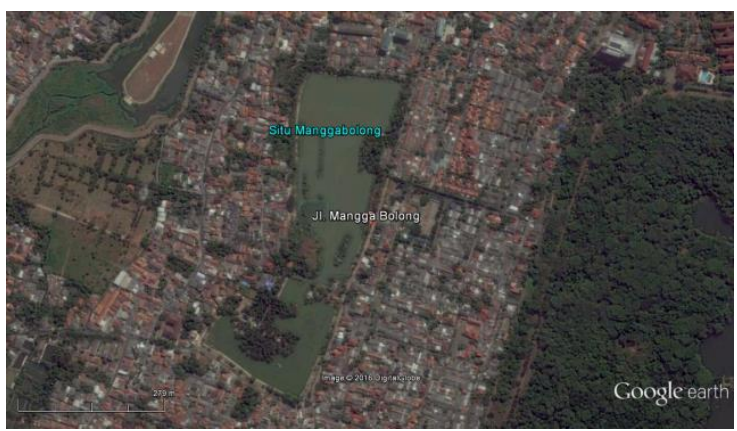

Gambar 5. Peta Citra Setu Mangga Bolong tahun 2015

(Sumber: Google Earth)

Gambar 8 menunjukkan hasil analisis SD. Kesan yang ditimbulkan pada lanskap dengan kualitas visual rendah yaitu Lanskap 6 seluruhnya bersifat negatif. Hal ini juga berlaku pada Lanskap 4. Adapun kesan yang ditimbulkan antara lain gersang, jelek, sempit, dangkal, prihatin, berantakan, keras, dan kotor. Faktanya kedua lanskap tersebut memiliki masalah yang sama yaitu banyaknya sampah dan pendangkalan. Sampah-sampah tersebut terjebak pada titik tersebut karena morfologi setu pada lokasi tersebut berupa cekungan. Selain itu, lokasi tersebut juga berdekatan dengan kedua inlet dari permukiman warga sekitar (Gambar 9). 


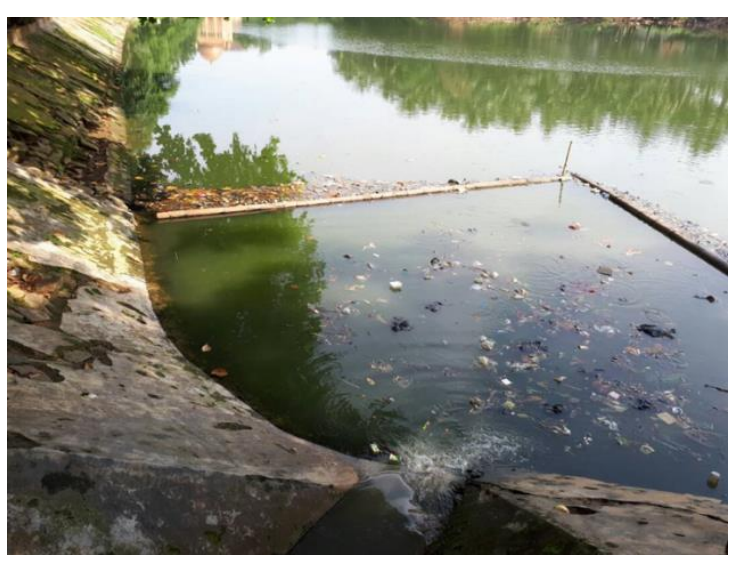

Gambar 6. Limbah Permukiman pada Inlet Setu Mangga Bolong (Sumber: Dokumentasi)

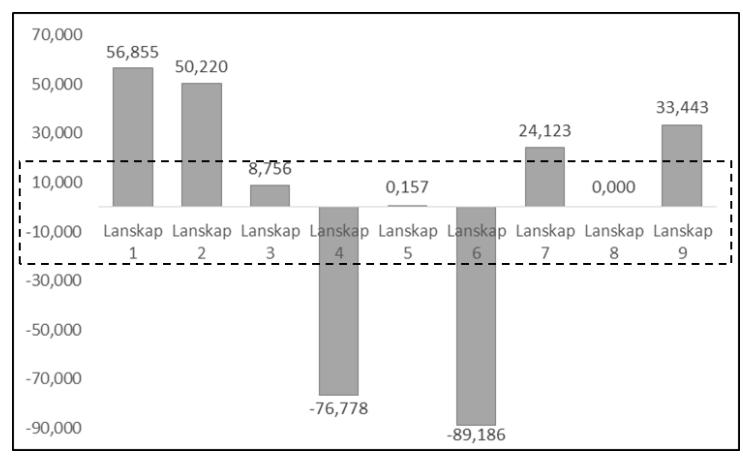

Gambar 7. Grafik Nilai SBE Setu Mangga Bolong (Sumber: Hasil Pengolahan Data)

Analisis MDS membantu untuk lebih memahami kesan yang ditimbulkan melalui dimensi penilaian langsung dari dari responden. Pola visualisasi kedekatan mengenai kesamaan lanskap Setu Mangga Bolong terlihat bahwa Lanskap 4 dan 6 berada pada kelompok lanskap dengan kualitas lanskap yang rendah dan lanskap lainnya berada pada kelompok lanskap yang tinggi (Gambar 10).

Lanskap 1 dan 2 merupakan dua lanskap dengan kualitas paling tinggi dari seluruh lanskap yang ada. Kedua lanskap tersebut hampir seluruhnya mewakili kesan positif. Faktor pembeda yang mengakibatkan lanskap 1 memiliki nilai kualitas visual yang lebih tinggi dari lanskap 2 yaitu Lanskap terkesan lebih luas. Lanskap 1 merupakan lanskap dengan area yang paling hijau di antara seluruh lanskap yang disajikan kepada responden. Selanjutnya, lanskap-lanskap dengan kualitas visual yang tinggi juga tampak hampir tidak terlihat elemen-elemen keras di sekitarnya (Gambar 11).
Hasil inventarisasi vegetasi menunjukkan terdapat sebanyak 40 spesies vegetasi eksisting sempadan Setu Mangga Bolong (Gambar 12). Kondisi vegetasi eksisting yang ada berada pada rentan baik hingga sangat baik. Adapun spesies sempadan Setu Mangga Bolong antara lain:

1. Pseudosasa japonica

2. Averrhoa bilimbi

3. Capsicum annum

4. Polyscias scutellaria

5. Durio zibethinus

6. Dracaena fragrans

7. Syzygium aqueum

8. Citrus aurantifolia

9. Plumeria rubra

10. Ipomoea aquatica

11. Annona muricata

12. Cocos nucifera

13. Elaeis guineensis

14. Muntingia calabura

15. Terminalia catappa

16. Terminalia mantaly

17. Mangifera indica

18. Pometia pinnata

19. Gnetum gnemon

20. Morinda citrifolia

21. Artocarpus heterophyllus

22. Oreodoxa regia

23. Carica papaya

24. Musa paradisiaca

25. Nephelium lappaceum

26. Ceiba pentandra

27. Cymbopogon nardus

28. Manihot esculenta

29. Annona squamosa

30. Annona muricata

31. Tabebuia chrysantha

32. Neliumbium nucifera

33. Colocasia esculenta

34. Aerva sanguinolenta

35. Canna sp.

36. Ruellia tuberosa

37. Albizia chinensis

38. Axonopus compressus

39. Bambusa sp.

40. Ipomoea batatas var. marguerite

Vegetasi eksisting perlu dijaga terutama jenis pohon selama tidak memberikan efek buruk bagi setu. Pertimbangannya yaitu adanya nilai penting pohon eksisting yang tidak dapat tergantingan apabila harus ditebang dan digantikan dengan vegetasi baru. Nilai-nilai penting tersebut misalnya kemampuan beradaptasi, menyerap polutan, mengikat tanah, dan habitat bagi makhluk hidup lainnya. Selain itu vegetasi eksisting juga dapat menjaga sense yang dimiliki oleh masyarakat 
yang telah turun-temurun memiliki hubungan dengan setu [17].

$\begin{array}{lllllll}-3 & -2 & -1 & 0 & 1 & 2 & 3\end{array}$

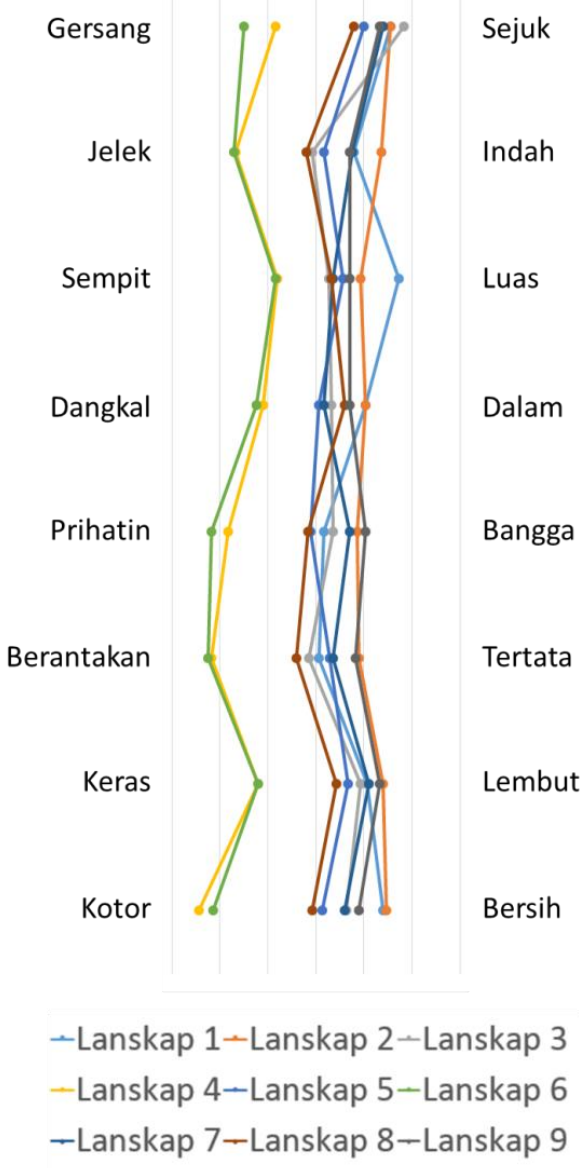

Gambar 8. Grafik Nilai SD Setu Mangga Bolong (Sumber: Hasil Pengolahan Data)

Berdasarkan Permen PU Nomor 5 Tahun 2008 tentang Pedoman Penyediaan dan Pemanfaatan Ruang Terbuka Hijau di Kawasan Perkotaan, dijabarkan mengenai dimensi sempadan. Dimensi setu minimal 50 meter dari titik pasang tertinggi. Kriteria pemilihan vegetasi untuk ruang terbuka hijau sempadan setu harus memenuhi kriteria relatif tahan terhadap penggenangan air, daya transpirasi rendah, serta memiliki sistem perakaran yang kuat dan dalam yang diharapkan dapat menahan erosi serta meningkatkan resapan air. Adapun vegetasi yang disarankan pada peraturan tersebut antara lain sebagai berikut:

1. Casuarina equisetifolia

2. Ficus elastica

3. Garcinia mangostana

4. Lagerstroemia speciosa

5. Cocos nucifera

6. Agathis loranthifolia

7. Filicium decipiens

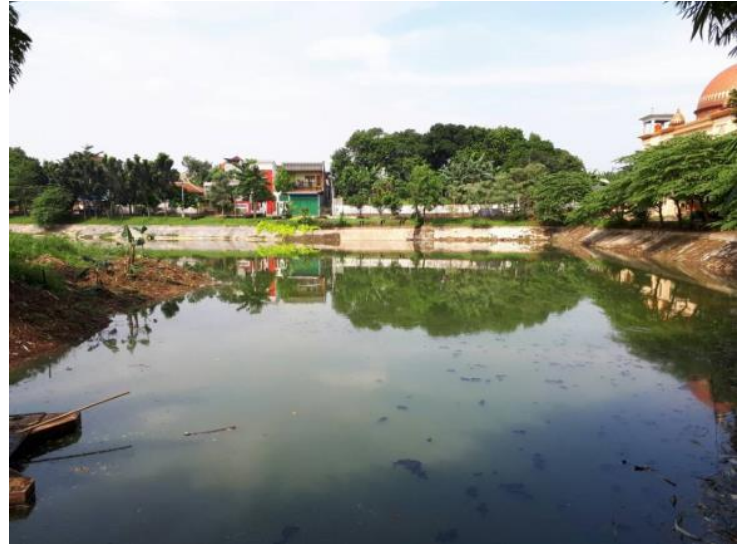

Gambar 9. Lanskap dengan Kualitas Visual Paling Rendah

(Sumber: Dokumentasi)

Gambar 13 menunjukkan delineasi garis sempadan setu sesuai dengan Permen PU Nomor 5 Tahun 2008. Warna merah menunjukkan wilayah sempadan setu sejauh 50 meter yang diambil dari tepi muka air setu yang pernah terjadi. Hal ini bertujuan untuk menjaga fungsi setu agar tidak terganggu oleh aktivitas yang ada di sekitar setu. Selain itu, hal ini bertujuan untuk menjamin kelestarian setu, termasuk kondisi vegetasi yang ada sehingga air setu memiliki kualitas dan kuantitas yang optimal. Dengan terjaganya kondisi vegetasi di sempadan setu, maka akan meningkatkan nilai manfaat setu, baik secara langsung maupun tidak langsung.

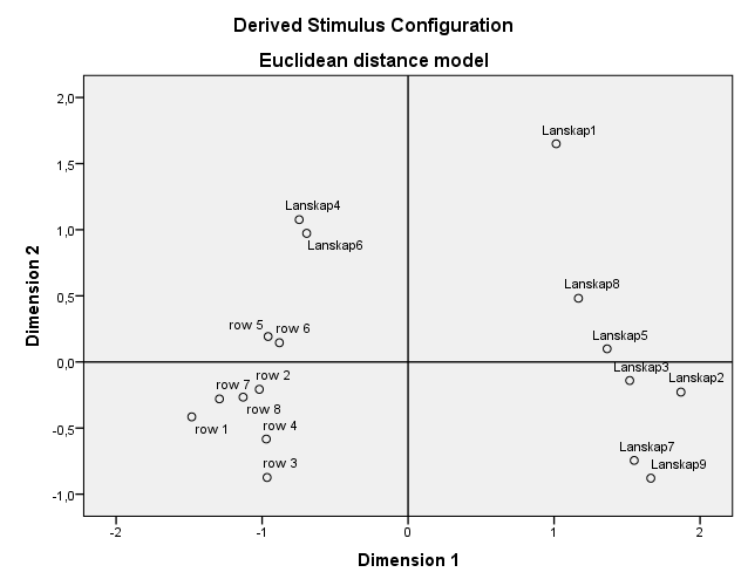

Gambar 10. Grafik MDS Setu Mangga Bolong (Sumber: Hasil Pengolahan Data)

Sejak zaman dahulu Jakarta terkenal sebagai area yang subur. Tak heran banyak penamaan area dengan menggunakan nama vegetasi. Masyarakat Betawi, sebagai etnis yang mendiami wilayah Jakarta pada zaman dulu dekat dengan budaya pertanian [18] [19]. Hal ini yang mendasari adanya produk-produk 
budaya Betawi yang memiliki karakter dari vegetasi [20] [21] [22].

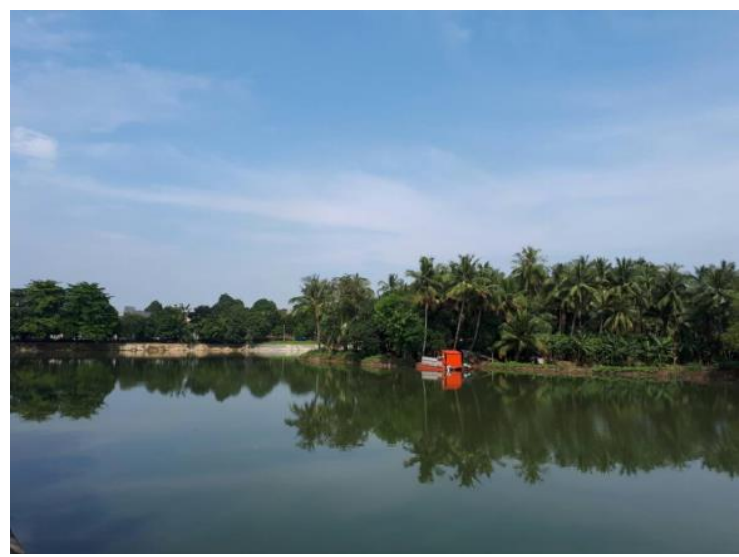

Gambar 11. Lanskap dengan Kualitas Visual Paling Tinggi

(Sumber: Dokumentasi)

Lokasi Setu Mangga Bolong yang berada di wilayah administrasi Kota Jakarta Selatan berbatasan dengan Kota Depok. Terdapat penggunaan lahan berupa Hutan Kampus UI serta beberapa setu yang ada di dalamnya. Hal ini menunjukkan bahwa wilayah ini merupakan daerah resapan air yang berperan dalam menjaga nilai ekologi kawasan. Semakin tingginya minat masyarakat untuk memiliki tempat tinggal juga memicu terjadinya konversi tata guna lahan kawasan hijau menjadi kawasan permukiman sehingga perlu upaya pengendalian pemanfaatan lahan.

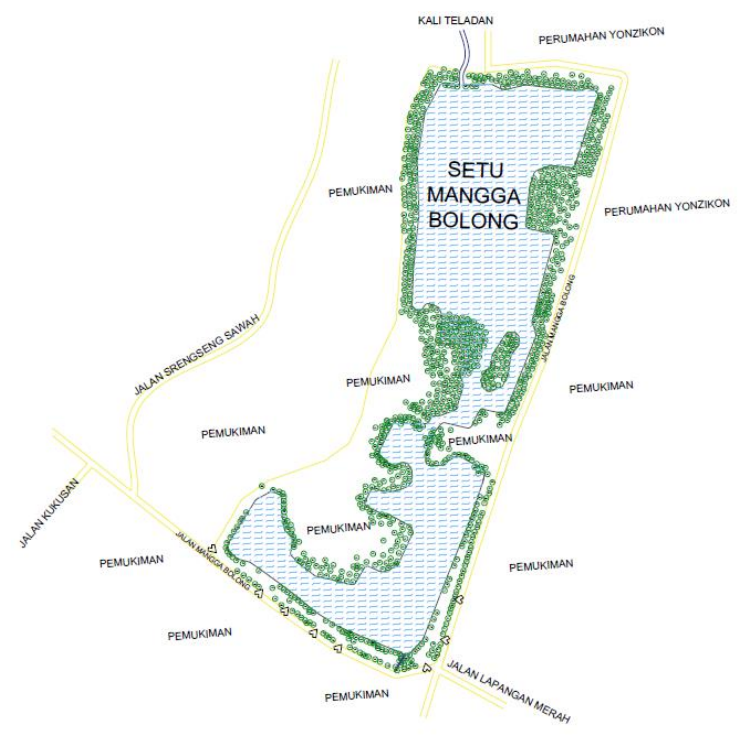

Gambar 12. Sebaran Vegetasi Eksisting Setu Mangga Bolong

(Sumber: Hasil Pengolahan Data)

Pada tahun 1987, diberlakukan SK oleh Pemerintah Provinsi DKI Jakarta mengenai vegetasi langka khas Betawi. SK tersebut merupakan SK Gubernur DKI Jakarta nomor 2359 tahun 1987. Vegetasi tersebut wajib dilestarikan karena mencirikan karakter khas budaya Betawi. Adapun vegetasi tersebut sebagai berikut:

1. Diospyros philippinensis

2. Annona reticulata

3. Antidesma reticulata

4. Lansium domesticum var. condet

5. Durio zibhentinus var. cipaku

6. Durio zibhentinus var. sitokong

7. Bouea macrophylla

8. Syzygium polycephalum

9. Eugenia jambos

10. Eugina cumini

11. Feronica lucida

12. Nephelium mutabile

13. Mangifera kemanga

14. Stelechocarpus burahol

15. Mangifera odorata

16. Floacourtia inermis

17. Litchi chinensis

18. Phyllanthus emblica

19. Morinda citrifolia

20. Baccaurea racemosa

21. Garcinia dulcis

Vegetasi khas Betawi saat ini terancam punah. $\mathrm{Hal}$ ini disebabkan jarangnya penggunaan vegetasi lokal dalam perencanaan lanskap Kota Jakarta baik secara mikro, meso, maupun makro. Penyebabnya antara lain perencana, perancang, maupun pengembang biasanya lebih memilih untuk menggunakan tanaman lanskap yang sedang trend, bibit tanaman sulit diperoleh, serta sedikitnya ruang hijau di kota untuk melestarikan vegetasi tersebut [23] [24] [25].

Nama 'Srengseng Sawah' sendiri merupakan toponimi yang menunjukkan historis kawasan sebagai lahan pertanian. Untuk memperkuat sense Srengseng Sawah sebagai wilayah bersejarah di Jakarta, perlu dikembangkan secara aktif penggunaan vegetasi eksisting maupun budidaya yang telah turun-temurun dikembangkan oleh masyarakat lokal. Pengembangan vegetasi eksisting secara tidak langsung melestarikan vegetasi lokal dan menguatkan eksistensi kebudayaan Betawi di kawasan Srengseng Sawah.

Hasil analisis menentukan konsep perencanaan tata hijau Setu Mangga Bolong (Gambar 14). Pada dasarnya konsep yang tawarkan mendukung upaya UPT PP Setu Babakan untuk menjadikan Setu Mangga Bolong sebagai area konservasi, namun tidak melupakan akar ekologis maupun budaya 
khususnya budaya Betawi. Setu merupakan fitur ekologis maka pada konsep ini pertimbangan utama dalam pembuatan konsep adalah aspek ekologis. Hal ini disebabkan apabila mengabaikan aspek ekologis, maka akan terjadi kerusakan yang tidak diharapkan pada setu. Masyarakat Betawi tidak memiliki langgam khusus dalam pemanfaatan setu. Kegiatan-kegiatan budaya yang terkait dengan setu hanya terbatas pada aktivitas memancing dan pertanian. Maka dari itu, aspek budaya yang menjadi perhatian di sini yaitu untuk mendukung aktivitas yang telah menjadi kebudayaan setempat dan juga lokasi penempatan vegetasi budaya pada sempadan setu tanpa harus mengancam fungsi ekologis dari setu.

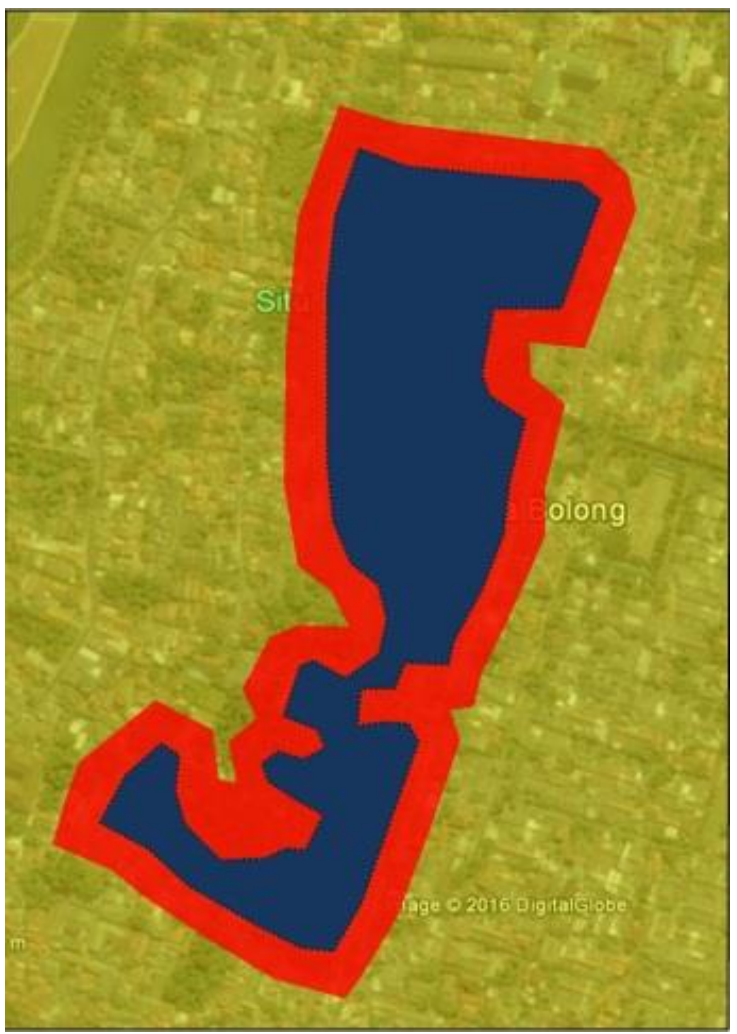

Gambar 13. Badan Air (biru), dan Sempadan Setu 50 Meter (merah)

(Sumber: Hasil Pengolahan Data)

Berdasarkan hasil analisis yang telah dilakukan, maka konsep tata hijau untuk Setu Mangga Bolong ada tujuh hal penting yang harus dipertimbangkan. Ketujuh hal tersebut antara lain:

1. Vegetasi yang direkomendasikan untuk penghijauan sempadan setu yaitu vegetasi dengan daya transpirasi rendah sesuai Permen PU Nomor 5 Tahun 2008 hingga radius 50 meter.
2. Vegetasi eksisting dipertahankan selama tidak mengganggu kualitas dan kuantitas badan air. Area terbangun pada radius 50 $\mathrm{m}$ harus dipulihkan. Apabila hal tersebut tidak memungkinkan maka pada area tersebut wajib memanfaatkan lahan pekarangan dengan menanam jenis vegetasi sesuai arahan Permen PU Nomor 5 Tahun 2008, yaitu tanaman dengan daya transpirasi rendah.

3. Tanaman manggis (Garcinia mangostana) disarankan ditanam untuk area terbangun (pekarangan) yang masuk dalam radius $50 \mathrm{~m}$ dari badan air karena bukan hanya memiliki fungsi ekologis tapi juga fungsi ekonomi dan pemenuhan gizi keluarga [26] [27].

4. Area di atas radius 50 meter dari badan air direkomendasikan untuk menggunakan vegetasi khas betawi. Seluruh tanaman tersebut bukan hanya unggul karena memiliki nilai budaya tetapi juga karena fungsi ekologis dan ekonomi. Tanaman-tanaman tersebut juga dapat membantu dalam pemenuhan gizi keluarga apabila diperuntukkan untuk konsumsi rumah tangga [28] [29].

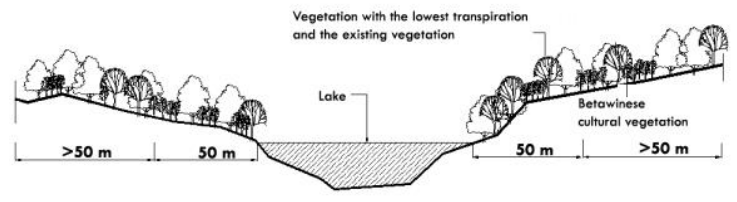

Gambar 14. Konsep Perencanaan Tata Hijau Setu Mangga Bolong

(Sumber: Hasil Pengolahan Data)

5. Area dengan kualitas visual paling rendah merupakan area paling prioritas untuk direhabilitasi agar kualitas visualnya meningkat.

6. Area dengan kualitas visual sedang dan tinggi perlu dipertahankan kualitas visualnya dengan pengelolaan yang tepat guna.

7. Pengelolaan setu yang intensif perlu diperhatikan pada sudut-sudut setu yang berbentuk cekungan dan juga sudut setu yang berdekatan dengan inlet. Hal yang mendasari rekomendasi ini karena banyaknya sampah yang terjebak pada kedua titik tersebut yang menyebabkan menurunnya kualitas visual serta kualitas lainnya pada Setu Mangga Bolong. 


\section{KESIMPULAN}

Kondisi badan air Setu Mangga Bolong pada periode 2005-2015 lebih baik dari tahun ke tahun. Meskipun demikian, terjadi penurunan area hijau di sepadan Setu Mangga Bolong selama periode tahun 2005-2015. Berdasarkan hasil analisis kualitas visual, lanskap pada area sudut setu yang berbentuk cekungan dan juga sudut setu yang berdekatan dengan inlet memiliki kualitas visual yang rendah. Hal ini disebabkan oleh banyaknya sampah, pendangkalan, dan juga kurangnya area hijau. Hasil inventarisasi vegetasi pada Setu Mangga Bolong tercatat terdapat empat puluh spesies vegetasi di sempadan setu. Untuk merencanakan tata hijau sempadan setu sebagai area konservasi tanaman bernilai ekologis dan budaya, vegetasi eksisting perlu dipertahankan selama tidak mengganggu kualitas dan kuantitas badan air. Selanjutnya Area terbangun pada radius 50 meter harus dipulihkan. Apabila hal tersebut tidak memungkinkan maka pada area tersebut wajib memanfaatkan lahan pekarangan dengan menanam 7 jenis vegetasi sesuai arahan Permen PU Nomor 5 Tahun 2008. Area di atas radius 50 meter dari badan air direkomendasikan untuk menggunakan 21 spesies vegetasi khas betawi.

\section{DAFTAR PUSTAKA}

[1] Forum Danau Dunia. (2004). Visi Danau Dunia Sebuah Ajakan Untuk Melakukan Tindakan. Jakarta: Forum Danau Dunia.

[2] Henny, C., Meutia, A.A. (2014). Water Quality and Quantity Issues of Urban Lakes in Megacity Jakarta. LIMNOTEK. 21: 2: 145-156.

[3] Henny, C., Meutia, A.A. (2014). Urban Lakes in Megacity Jakarta: Risk and Management for Future Sustainability. Procedia Environmental Sciences. 20: 2014: 737-746.

[4] Maryetti, S., Sulistyadi, Y., Damanik, D., Nurhidayati, H., Wibowo, F.X.S. (2016). Pengembangan Berkelanjutan Kampung Budaya Setu Babakan Sebagai Daya Tarik Wisata. Jurnal Destinasi Kepariwisataan Indonesia. 1: 1: 27-43.

[5] Wardiningsih, S. (2014). Lanskap Budaya Wisata Budaya Betawi (Studi Kasus Kota Tua Jakarta Kota). Jurnal Arsitektur NALARs. 13: 2: 117-122.

[6] Yuwono, S., Wardiningsih, S. (2016). Mempertahankan Keberadaan Kampung di Tengah-Tengah Kawasan Modern Jakarta. Jurnal Arsitektur NALARs. 15: 1: 73-80.
[7] Moechtar, S., Sarwadana, S.M, Semarajaya, C.G.A. (2012). Identifikasi Pola Permukiman Tradisional Kampung Budaya Betawi Setu Babakan, Kelurahan Srengseng Sawah, Kecamatan Jagakarsa, Kota Administrasi Jakarta Selatan, Provinsi DKI Jakarta. E-Jurnal Agroekoteknologi Tropika. 1: 2: 135-143.

[8] Baron. (2011). Perhatikan Setu Mangga Bolong!. Berita Batavia. http://www.beritabatavia.com/detail/2011/04 /06/6/6616/perhatikan.setu.mangga.bolong \#.WQByQLglHIV. [1 November 2016].

[9] Wardiningsih, S. (2005). Rencana Pengelolaan Lanskap Perkampungan Budaya Betawi di Setu BabakanSrengseng Sawah, Kecamatan Jagakarsa-Jakarta Selatan. Tesis. Bogor: IPB.

[10] Martiyanti E. (2015). Ahok Perintahkan Kadis Tata Air Keruk Sungai Dangkal. Berita Jakarta. http://www.beritajakarta.com/read/12396/ah ok-perintahkan-kadis-tata-air-keruk-sungaidangkal\#.WB4USS197cc. [1 November 2016].

[11] Rachmi. (2015). Bersih bersih di Setu Mangga Bolong - Jagakarsa. Poskotanews. http://poskotanews.com/2015/03/22/bersihbersih-di-setu-mangga-bolong-jagakarsa/. [1 November 2016].

[12] Bodnár, R.K. (2011). Tourist Aspects of Assessing Landscape Change. GeoJournal of Tourism and Geosites. 7: 1:39-50.

[13] Daniel, C., Boster, R.S. (1976). Measuring Landscape Aesthetic: The Scenic Beauty Estimation Method. New Jersey: USDA.

[14] Osgood, C.E., Suci G.J, Tannenbaum, P.H. (1975). The Measure of Meaning. Urbana: University of Illinois Press.

[15] Fauzi, F. (2016). Analisis Potensi Wisata Situ Ciledug dan Situ Gintung di Kota Tangerang Selatan. Jurnal Pro-Life. 3: 2: 84-96.

[16] Sitorus, S.R.P., Aurelia, W., Panuju, D.R. (2011). Analisis Perubahan Luas Ruang Terbuka Hijau dan Faktor-Faktor Yang Mempengaruhinya di Jakarta Selatan. Jurnal Lanskap Indonesia. 2: 1: 15-20.

[17] Syahadat, R.M., Putra, P.T. Alfian, R. Nailufar, B. (2016). Mengembalikan Mata Air Umbulan, Menyelamatkan Sense Masyarakat Lokal. Prosiding Temu IImiah IPLBI 2016. A: 055-058.

[18] Suryana, A. (2012). Pasar Mingqu Tempo Doeloe Dinamika Sosial Ekonomi Petani Buah 1921-1966. Jakarta: LIPI. 
[19] Hidayah, Z. (2015). Ensiklopedi Suku Bangsa di Indonesia. Jakarta: Yayasan Pustaka Obor Indonesia.

[20] Chaer. A. (2012). Folklor Betawi Kebudayaan dan Kehidupan Orang Betawi. Jakarta: Masup Jakarta.

[21] Zaenudin, H.M. (2012). 212 Asal-Usul Djakarta Tempo Doeloe Diserti Fakta, Foto, dan Kesaksian Unik yang Membawa Anda ke Masa Lalu. Jakarta: Ufuk Press.

[22] Zaenudin, H.M. (2013). Asal-Usul KotaKota di Indonesia Tempo Doeloe. Jakarta: Change.

[23] Febrianti, N., Sofan, P. (2014). Ruang Terbuka Hijau di DKI Jakarta Berdasarkan Analisis Spasial dan Spektral Data Landsat 8. Prosiding Seminar Nasional Penginderaan Jauh 2014. 498-504.

[24] Dwiyanto, A. (2009). Kuantitas dan Kualitas Ruang Terbuka Hijau di Permukiman Perkotaan. Teknik. 30: 9: 8893.

[25] Syahadat, R.M. (2013). Tanaman Obat Tradisional Indonesia, Potensi Lain yang Belum Dioptimalkan dari Sudut Pandang Arsitektur Lanskap. Wacana untuk Negeri Bunga Rampai Pemikiran Mahasiswa Pascasariana IPB. Bogor: IPB Press. 4245.

[26] Bahruni, Suhendang, E., Darusman, D., Alikodra, H.S. (2007). Pendekatan Sistem Dalam Pendugaan Nilai Ekonomi Total Ekosistem Hutan: Nilai Guna Hasil Hutan Kayu dan Non Kayu. Jurnal Penelitian Sosial dan Ekonomi Kehutanan. 4: 3: 369-378.

[27] Asmara, R., Hanani1, N., Suryaningtyas, R. (2011). Analisis Usahatani Manggis dan Faktor-Faktor Sosial Ekonomi yang Mempengaruhi Keputusan Petani Memasarkan Hasil Usahatani Manggis dengan Sistem ljon. AGRISE. 11: 2: 129137.

[28] Ashari, Saptana, Purwantini, T.B. (2011). Potensi dan Prospek Pemanfaatan Lahan Pekarangan untuk Mendukung Ketahanan Pangan. Forum Penelitian Agro Ekonomi. 30: 1: 13-30.

[29] Rahayu, M., Prawiroatmodjo, S. (2005). Keanekaragaman Tanaman Pekarangan dan Pemanfaatannya di Desa Lampeapi, Pulau Wawoni Sulawesi Tenggara. J. Tek. Ling.P3TL - BPPT, 6: 2: 360-364. 